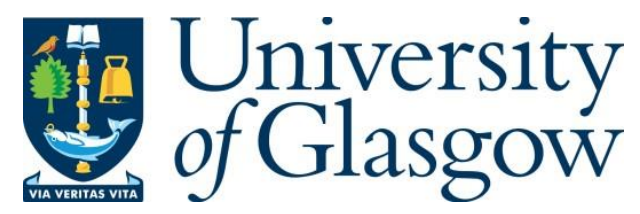

Duncan, A. and Nolan, C. (2019) Reform of the UK Financial Policy Committee. Scottish Journal of Political Economy (doi:10.1111/sjpe.12228)

There may be differences between this version and the published version. You are advised to consult the publisher's version if you wish to cite from it.

This is the peer reviewed version of the following article, Duncan, A. and Nolan, C. (2019) Reform of the UK Financial Policy Committee. Scottish Journal of Political Economy, which has been published in final form at http://dx.doi.org/10.1111/sjpe.12228. This article may be used for non-commercial purposes in accordance with Wiley Terms and Conditions for Self-Archiving.

http://eprints.gla.ac.uk/188864/

Deposited on: 21 June 2019

Enlighten - Research publications by members of the University of Glasgow http://eprints.gla.ac.uk 


\title{
Reform of the UK Financial Policy Committee*
}

\author{
Alfred Duncan ${ }^{\dagger}$ \\ University of Kent \\ Charles Nolan ${ }^{\ddagger}$ \\ University of Glasgow
}

May 2019

\begin{abstract}
We argue that: The FPC should have a wider remit; a much broader membership (covering many specialisms); should be wholly independent of Government and outside the Bank of England; its aim should be to comment publicly and authoritatively on any possible areas of risk to financial stability whilst itself controlling few if any levers of policy.

The rationale for these conclusions is that: Macroprudential/financial risks come from many sources; many of these sources are structural and outside of the Bank's regulatory purview/competence; in a sense the Bank gets to mark its own homework as regards issues such as the SMR, Resolution, appropriateness of capital, effectiveness of ring-fencing etc.; many aspects of macroprudential actions have distributional implications, and so politicians, not the Bank or any other body, should take and justify, or not, these decisions.
\end{abstract}

JEL Classification: E13, E44; G11; G24;G28.

Keywords: Keywords: Macroprudential policy; monetary economics; risk; financial markets.

${ }^{*}$ Without implicating, we thank for helpful comments: Emilios Avgouleas, Willem Buiter, Jagjit Chadha, Douglas Gale, Charles Goodhart, Campbell Leith, John Muellbauer, Christoph Thoenissen, John Tsoukalas, Sir Paul Tucker and seminar participants at the MMF UK Monetary and Financial Conference, Strathclyde University, Glasgow University, and the Scottish Economic Society Conference 2019. We also thank a referee of the journal for very helpful suggestions.

${ }^{\dagger}$ Email: a.j.m.duncan@kent.ac.uk. School of Economics, University of Kent, Canterbury CT2 7NP, United Kingdom.

†Email: Charles. Nolan@glasgow.ac.uk. Department of Economics, Adam Smith Business School, University of Glasgow, Glasgow G12 8QQ, United Kingdom. 


\section{Objectives and Challenges of Macroprudential Policy}

As a result of the 2007/8 financial crisis, many policymakers would now argue financial regulation and macroeconomic policy are joint policy problems. In practice, that has led to few, if any, substantive changes to monetary and fiscal policy rules. It has led to many changes in the financial supervisory architecture and a macroprudential perspective may become a key component in economic policy.

The UK has been at the forefront of developments. Along with the global move towards increased capital and liquidity requirements for banks and other financial intermediaries, the enactment of the Vickers Commission proposals and the reorganization of the Bank of England, in particular the establishment of the Financial Policy Committee (FPC), have been amongst the most striking institutional developments anywhere. The FPC, whose statutory responsibility is to aid the Bank in enhancing the stability of the UK financial system, has also been granted additional, far-reaching powers, such as those to limit aggregate bank exposure to the property market.

In this paper, we argue that an optimal macroprudential framework ought to concern itself with issues somewhat wider than countercyclical capital buffers, leverage ratios and the like. Not only is the intersection between microprudential and macroprudential measures larger than typically acknowledged, macroprudential oversight ought to have in its purview to assess the efficiency of the financial system and its constituent parts and recommend action. Macroprudential regulators should be actively concerned with a wide range of policy areas such as corporate governance, competition and tax policy. The significance of these areas for macroprudential policy follows directly from a concern for financial efficiency since the larger are the wedges of inefficiency, the 
more damaging negative shocks to and from the financial system are likely to be.

To be clear, we are not proposing that the FPC takes on huge extra responsibilities, devises lots more rules, much less becomes an 'omni-regulator'! Rather, the hope is the opposite and that by helping to identify key areas of inefficiency in the financial system fewer ad hoc policy adjustments may be required. We outline some specific proposals at the end of the paper which would help, in our view, to improve the UK framework. These would give the FPC an influential voice in identifying potential problems facing financial stability whilst in many instances leaving decisions on policy remedies with politicians or other authorities $^{1}$. However, clearly any extension of the FPC's sphere of influence (along with the Bank's) has implications for accountability. As we suggest, it may be that the FPC should not be located within the Bank of England. Consequently, whilst there are indeed difficult judgments as regards stability and efficiency objectives, as explained in Sargent (2011) and more recently in Aikman et al. (2019), we argue it is necessary to consider the joint design of macroprudential institutions and macroprudential policies, something largely overlooked in existing academic and policy discussions.

The argument in more detail The conventional view of financial regulation is that microprudential regulators try to induce efficient behaviour of regulated institutions, whilst macroprudential regulation knocks out any systemic externality leaving monetary policy unencumbered by financial frictions. We argue that the issue is somewhat more complicated.

Macroprudential policy confronts various externalities emerging from the

\footnotetext{
${ }^{1}$ At a recent conference to mark 20 years since the Bank of England was given independence, a number of influential speakers raised concerns about the Bank's independence and autonomy. In part these concerns stem from what some, including the present authors, worry is an over reliance under the current framework on the Bank to take what are in effect political decisions. See the discussion below.
} 
financial sector. In this paper we focus principally on four, not all of which have received equal amounts of attention in the literature. First, there are what we term leverage externalities stressed by Fisher (1933) then later formalised by Bernanke et al. (1999) and Kiyotaki and Moore (1997). ${ }^{2}$ Next, there are monetary transmission externalities highlighted by Friedman and Schwartz (1963) and Farhi and Werning (2013). Third, there are bailout externalities associated with the toobig-to-fail problem analyzed, for example, in Haldane (2012). And finally, there are herding externalities studied in Duncan (2015) and Farhi and Tirole (2012). We argue that time-varying capital requirements or lending restrictions centred on banks - for some the defining characteristic of macroprudential policy - are at best insufficient in addressing the impact of these and other externalities. These externalities, not all of them concentrated in the more regulated areas of the financial sector, interact with one another and with other areas of policy.

For instance, whilst experience suggests balance sheet recessions associated with high leverage are costly even if monetary policy is unconstrained by the zero lower bound (ZLB), the effects of these externalities are seriously compounded when the monetary transmission mechanism is compromised (Friedman and Schwartz, 1963; Farhi and Werning, 2013; Schmitt-Grohe and Uribe, 2012). And although some monetary policy innovations (such as Quantitative Easing, Forward Guidance and negative interest rate policy) ameliorate these monetary transmission externalities, other measures are likely required. However, such measures, including deposit insurance and central bank/taxpayer assistance (for example, in the form of emergency liquidity and insurance, and bailouts), come with serious incentive costs exacerbating the too-big-too-fail (TBTF) problem and herding effects. Moreover, these TBTF and herding effects are in turn likely to

\footnotetext{
${ }^{2}$ Leverage concentrates the losses associated with business cycles on debtors, encouraging fire sales that further depress asset prices and economic activity.
} 
feed back and exacerbate the leverage externality.

Similarly, the TBTF problem may be addressed via microprudential measures, including the resolution regime. However, as large banks are likely to become vulnerable during periods when other institutions and markets are also stressed, the TBTF problem is of central importance to macro policymakers. We argue that it is far from clear that recent regulatory measures resolve the TBTF problem nor that breaking up banks is obviously preferable. If 'smaller' financial institutions' asset profiles are highly correlated, they too pose a collective systemic risk as well as being a higher regulatory burden.

The following sections describe these examples in detail as well as outlining further interactions between macroprudential policy and other policies, including taxation. In short, the overlap between macroprudential concerns and microprudential regulation is large, complex and evolving.

Further complications of macroprudential policy In addition to the complications just noted, we suggest that macroprudential policy faces three important challenges: First, macroprudential interventions typically have important distributional consequences. Second, it is difficult to determine the success or failure of macroprudential policy interventions in reasonable time. Third, it may be difficult to communicate the motivation for some macroprudential policy interventions.

These challenges combine to give rise to concerns over how best to design the institution of the macroprudential regulator. What instruments should they be assigned? What targets should they be set? To what extent should they be able to deploy their instruments unilaterally? What kind of oversight mechanisms can be imposed to ensure their effectiveness and legitimacy? Who should be involved in policy decisions? Sensible answers to these questions must trade off 
the potential financial stability and efficiency benefits of different macroprudential policy interventions with political realities. ${ }^{3}$ We conclude the paper with a set of tentative recommendations on how the FPC might evolve in its role as the macroprudential regulator. Perhaps our key suggestion is that the FPC be given wider obligations to assess the efficiency, as well as enhancing the stability, of the financial system. Such a role could entail providing authoritative, public advice on potentially a number of areas of public and private policy, such as the tax system, corporate governance, pay structures and accounting practices. An implication of that role is that the composition of the FPC ought to be widened. And there is also a case that the FPC should no longer be located in the Bank of England. That is because it is mandated to support Government policy and may be reticent or unable to question policies which are unhelpful from a financial stability perspective. Perhaps more important, other areas of the Bank are repsonsible for many aspects of the regulatory regime; how willing might the FPC be to question the effectiveness of, say, of the Senior Managers Regime or new Resolution procedures? The FPC currently implicitly assumes, in its periodic assessements of risks to financial stability, that these and other areas for which it has responsibility pose no risk to wider financial stability.

The next section of the paper provides a definition and brief summary of the standard view of macroprudential policy. It is discussed further in an appendix. The paper then turns to the current UK framework and what we label as the premises underlying it and why the FPC's remit may be too narrow. The literature on 'financial frictions' is selectively reviewed and we identify what we think are key policy issues. That assessment is boken into various subjects such as TBTF (too big to fail), monetary policy, tax policy, pay and incentives facing bankers and

\footnotetext{
${ }^{3}$ Dixit (1998) makes the case more generally that the technical problem of determining optimal policy interventions should not be separated from the political problem of institutional design.
} 
shareholders and the legitimacy of the macroprudential authority. In doing this, we are led to question the robustness of the premises of the UK macroprudential framework-specifically its scope and legitimacy. The paper concludes with some tentative recommendations on policies and institutions that may help develop a more effective and accountable macroprudential regime.

\section{A brief overview of macroprudential policy}

A large part of the justification for micro-prudential policies is widely, though not universally, agreed upon: If the costs of bank failure are passed on to taxpayers through deposit insurance or likely bailouts, and the benefits of bank risk taking enjoyed by bank managers and shareholders, then banks will have an incentive to take on excessive leverage and risk. ${ }^{4}$

In a short appendix to this paper, we discuss further the evolution of policymakers' thinking on macroprudential policy. However, neither in the academic literature nor amongst policymakers is there a widely agreed position on the proper scope, tools and objectives of macroprudential policies nor of their coordination across countries (see e.g., the discussion in Cunliffe, 2015). That said, the idea that macroprudential policies address externalities that compromise in particular monetary policy appears to be more widely accepted. This is reflected in recent developments in the UK.

\subsection{Consensus View of UK Macroprudential Oversight}

In addition to the capital and liquidity requirements of Basel III $^{5}$, the most significant developments in macroprudential policy in the UK since the crisis have

\footnotetext{
${ }^{4}$ That point has been made many times, recently, and perhaps most forcefully, by Admati and Hellwig (2013).

${ }^{5}$ As implemented through Capital Requirements Directive IV.
} 
been:

1. The dominant role that the central bank, the Bank of England, is accorded in micro and macroprudential oversight;

2. Related to the first development, but distinct, is the establishment of a macroprudential authority (the FPC) with statutory responsibilities and powers (e.g., to advise on capital requirements and the ability to issue directions to the PRA and the FCA to amend microprudential regulations);

3. The enactment of the Vickers Commission proposals for ring-fencing of retail banks. (2019 for full implementation).

However, as noted above, nothing has changed in terms of monetary and fiscal rules. We suggest that these developments are based on the following five premises (P1.-P5.) which may be regarded as the consensus view underlying actual macroprudential oversight:

P1. Macropru, operating via micropru, should work to reduce the likelihood and severity $^{6}$ of crises. Macropru is about making sure financial frictions do not interfere with the normal operation of monetary policy.

P2. There is little or no need for an inflation-targeting monetary authority to take account of financial factors; financial frictions are largely invariant to the nominal regime.

The gist of Premises 1 and 2 is that the systematic component of monetary policy ought not to be part of macroprudential policy.

\footnotetext{
${ }^{6}$ Reducing severity has two aspects. The first is to formulate rules ex ante that boost the resilience of the financial system to shocks. The second is having the ability to act speedily, effectively and with requisite powers once a crisis has struck.
} 
P3. There is no need for fiscal policymakers/politicians/tax policy to have a systematic role in setting macroprudential policy. Specifically, time-varying taxes are unnecessary.

P4. Prior to the financial crisis some banks, in part due to "hidden" subsidies, had become too big to fail (TBTF). Ending universal banking, increased capital requirements and overhauled recovery and resolution are the key to ending TBTF.

P5. Macroprudential regulation should be applied to entities, rather than activities. In particular, the primary focus of regulation should be banks.

We are not claiming that these premises, as set out, represent the stated policies of the relevant UK authorities. However, as we document below, they reflect much academic thinking on these issues along with that of senior UK policymakers, which we detail presently.

Premises 1. -5 . are important for two reasons. First, they may be employed to justify a dominant role for the central bank in the formulation of macroprudential regulation and crisis management: Any factors that might disrupt the conduct of monetary policy could be seen to compromise the independence of the central bank. It may then be argued that any influence upon those factors should be exercised and coordinated by the central bank itself. Second, they may be used to rationalize what we will argue is an overly narrow focus for the FPC, centred largely on time- varying capital surcharges on regulated banks.

\section{What are the Bank's formal objectives and strategy and why do we argue that they are 'too narrow'?}

The Bank's formal financial stability objective, set out in the Bank of England Act 1998, as amended by the 2012 Act, is to 'protect and enhance the stability of the 
financial system of the United Kingdom'. Section 9C of the Act sets out the FPC's objectives as (a) contributing to the achievement by the Bank of the Financial Stability Objective, and (b) subject to that, supporting the economic policy of Her Majesty's Government, including its objectives for growth and employment. Section 9 goes on to imply that the FPC's remit is limited to financial institutions and markets. Section 3A of the 2012 Act charges (a sub-committee of) the Court of Directors of the Bank with formulating the Bank's Financial Stability strategy and with monitoring the FPC's performance in that regard. As empowered to do so under the Act, Court has delegated the review of the strategy to the Financial Policy Committee (FPC) although the Court retains ultimate responsibility for the strategy.

The Bank's Financial Stability Strategy, in turn, has three elements: (a) Establishing a rigorous baseline level of resilience to protect the UK real economy. This covers prudential regulation; that is efforts to make robust regulated financial entities. (b) Ensuring the level of resilience adapts to the possible shocks the system might face. This covers efforts (e.g. via stress testing) to identify latent risks to financial stability. (c) Enabling the system to absorb shocks, if/when they occur, so it can continue to support the economy. This speaks to efforts to alleviate crises when they have materialised. In questioning Premises 1.-5., we will argue that macroprudential concerns cover areas not typically within the scope of central bank expertise and that cut across overtly political terrain. Moreover, macroprudential risks are associated with structural features of the financial system and the wider economy. However, most policy discussion focuses on cyclical changes to capital buffers in the regulated sector of the financial system. That raises a central tension, as we see it, between the current overly narrow focus of UK macroprudential policy and an expanded role for the Bank of England that would necessarily exacerbate questions around legitimacy. 
Why do we argue that the FPC's focus is overly narrow? First, it is essentially prohibited under the Act, and as an arm of Government, from commenting critically on tax and other policies (for example, land planning laws, decisions on taxation of bank profits, tax incentives for debt over equity) that may have an important bearing on structural sources of financial fragility. Second, the fundamental focus of the 1998 Act as amended by the 2012 Act is that the Bank and the FPC concentrate on the financial system, largely the regulated part. The financial system's regulatory perimeter is reviewed but there is little assessment whether the non-financial system also poses increasing risks to financial stability. Third, the FPC gets to mark its own homework insofar as the Financial Stability Report is concerned: issues related to resolution, bank capital surcharges, the too-big-to-fail problem, financial sector pay and governance, and so on, appear not to be identified as possible sources of systemic threat in Reports, presumably because policies are in place and are assumed effective. Fourth, as argued earlier, the externalities that motivate a macroprudential perspective in policies interact in ways that may exacerbate one another. There appears to be scope for taking these interaction risks more seriously in the Financial Stability Reports. We discuss these issues further below.

Hence a key question is: How secure are these premises? In the rest of the paper we try to answer that question drawing on both the academic literature and recent policy developments. That assessment leads us to question the robustness of these premises and in doing so to suggest that the focus of macroprudential policy ought to be somewhat wider than at present. That conclusion, in turn, attenuates extant questions of legitimacy surrounding FPC interventions that are raised later in the paper. And so, we conclude that the composition and role of the FPC ought to be changed in substantive ways to cope with issues both of optimal scope and legitimacy. 


\section{Monetary policy}

Creating the FPC inside the Bank of England ${ }^{7}$ reflects a perceived tight link between monetary policy and financial stability, as well as the historical responsibilities of central banks to ensure financial stability in addition to meeting inflation and employment stability targets. Our discussion of that link starts by considering the centrality of stability in the monetary transmission mechanism in motivating a role for macroprudential policy, before turning to the question of how the FPC should respond to technical innovations in the practise of monetary policy. Finally, we review the literature on the interaction between monetary policy targets and financial stability.

\subsection{The scope of macroprudential policy: more than just monetary stability}

P1. Macropru, operating via micropru, should work to reduce the likelihood and severity of crises. Macropru is about making sure financial frictions do not interfere with the normal operation of monetary policy. ${ }^{8}$ Macroprudential policy is, from this perspective, any prudential rule or regulation that is intended to permit monetary (and fiscal)

\footnotetext{
${ }^{7}$ Formally, the FPC is a statutory sub-committee of the Court of the Bank of England. That makes it different to the MPC which is a committee of The Bank. It is not clear to us that this legal distinction is material although there has been some discussion about this.

${ }^{8}$ For example, Tucker et al. (2013, Page 193) notes that: "The crisis has underlined the importance of financial stability as a precondition for monetary stability and broader economic health and prosperity." Or again, drawing on early work on macroprudential regulation developed by Andrew Crockett, Claudio Borio and others at the BIS, Cunliffe (2015) states "Macroprudential authorities like the FPC use many of the same instruments as microprudential regulators such as bank capital standards. And in the very final resort, monetary policy may need to be used to counter financial stability risk." Finally, whilst discussing the possibly destabilizing asset allocation decisions in the asset management industry, Haldane (2014) argues that ".. a natural first line of defence against such swings is so-called macro-prudential policy." (page 13). It is worth noting that he makes this point whilst discussing Stein's argument that monetary policy may have a comparative advantage in such situations.
} 
policy to operate as 'normal'. As noted policymakers have been reluctant to change monetary and fiscal frameworks following the crisis preferring instead to change the way they supervise the financial sector, in particular the banking sector. That perspective actually has a long history.

Friedman and Schwartz (1963) and Friedman (1982, 1994) argue forcefully that the Fed's policy failures following the Crash of 1929 in the US allowed the Great Depression to persist long after it should have ended. That was because by not ending bank runs, something he argued it lacked the will to do, the Fed made it impossible for the money supply to grow, a sine qua non in his view for stable nominal income growth. The establishment of the FDIC in 1933 was said by Friedman (1994) to be "the most important structural change in our monetary institutions since at least 1914". ${ }^{9}$ Friedman argued that the FDIC ended bank runs, allowed the money supply to start growing and returned the economy to a more stable growth path.

Significantly, Friedman argued that the FDIC notwithstanding, banks' shareholders would ensure that banks did not become too risky, apparently rejecting the risk of moral hazard. ${ }^{10}$ Of course, not everyone would fully agree with Friedman's account of these events but the essential point for present purposes is that an additional regulation, deposit protection, was proposed to ensure monetary stability. In other words, the establishment of the FDIC was a form of

\footnotetext{
${ }^{9}$ Friedman seems to be referring to the founding of the Fed which was signed into law on December 23 1913. He and Schwartz (1963) wrote: “...we regard federal deposit insurance as so important a change in our banking structure and as contributing so greatly to monetary stability - in practice far more than the establishment of the Federal Reserve System."

${ }^{10}$ Shareholders' incentives to monitor banks and enforce prudent managerial behavior was, Friedman later argued (in Money Mischief, 1994), destroyed by the Fed: The inflation of the 1970s, largely, he argued, the fault of the Fed, wiped out shareholder net worth (as the real cost of funds outstripped revenue on loans). After that, the FDIC became, Friedman conceded, a source of financial instability. His solution was to recommend abolishing the Fed and restrict banks to holding $100 \%$ reserves. Rockoff (2010) is a very interesting comparison of Adam Smith's and Milton Friedman's of the banking firm.
} 
macroprudential regulation, although clearly such labels were not then employed. Farhi and Werning (2013) is a modern restatement of that perspective, in some respects. They argue that macroprudential restrictions may be necessary in order to ensure that, following adverse shocks, the Bank Rate never hits the ZLB and monetary policy is compromised in its ability to support economic activity.

But Friedman's argument seemed to be incomplete along a number of dimensions. First, deposit insurance entails a moral hazard problem and that, in turn, can have systemic implications (Kareken and Wallace, 1978). Second, not every country followed the US example and instituted (de jure) deposit protection: in the UK deposit protection was finally introduced in 1979 as part of incorporating European legislation on the UK statute book. Nevertheless traditional bank runs were not a serious problem, actually any kind of problem at all, for a large part of the post war period in either the UK or US ${ }^{11}$. That said, in the UK and elsewhere there were periodic banking difficulties, some of them serious ${ }^{12}$, and there was a clear trend internationally towards developing micro-prudential regulation.

Since the onset of the Great Recession, policymakers in the UK and in many countries have successfully maintained the stability of the banking sector. The major threat to monetary policy transmission has instead been the zero lower bound on interest rates (see Hall, 2011, and Christiano, Eichenbaum, and Trabandt, 2015) and the elimination of zero lower bound episodes has been a goal of research in macroprudential policy (Farhi and Werning, 2013). In sum, it is clear that an important role of macroprudential policy is to maintain the effectiveness of monetary policy.

But leverage externalities still have avoidable macroeconomic consequences

\footnotetext{
${ }^{11}$ Northern Rock was the first retail bank run in the UK in 150 years.

${ }^{12}$ Perhaps most notable in the UK is the secondary banking crisis in the early 1970 s.
} 
even when the monetary transmission mechanism remains effective. Countries including New Zealand and Australia suffered from the consequences of leverage externalities during the Global Financial Crisis even though they retained control of the money supply and inflation. Indeed, much of the literature developing the theory of leverage externalities and their macroeconomic costs abstracts from monetary policy entirely (Bernanke and Gertler, 1989; Kiyotaki and Moore, 1997). Influential empirical estimates of the business cycle costs of leverage externalities do not rely on failure of the monetary transmission mechanism (Nolan and Thoenissen, 2009; Jermann and Quadrini, 2012; Christiano, Motto, and Rostagno, 2014). The broad message is that macroprudential policymakers should be concerned with issues that affect leverage externalities, beyond ensuring the effectiveness of monetary transmission. These issues include deposit subsidies, herding, irrational exuberance, rational bubbles, poor contract design, and tax distortions.

\subsection{The interaction with the practise of monetary policy}

In recent years there has been a number of innovations in the practise of monetary policy, which are intended to increase the effectiveness of monetary policy in periods of financial stress. These innovations include Forward Guidance, Quantitative Easing and the use of interest rate corridors on reserve balances. ${ }^{13}$ These measures have all been implemented by the Bank of England. Some authors, notably Buiter (2009), Kimball ${ }^{14}$ and Rogoff (2014), have also suggested that the use of paper currency should be eliminated or severely curtailed in order to allow

\footnotetext{
${ }^{13}$ This includes paying interest on reserves, which can reduce the potential costs of Quantitative Easing as it allows the Central Bank to retain control over short term policy interest rates even when there is a large supply of reserves (Woodford, 2001).

${ }^{14}$ See http://blog. supplysideliberal.com/post/62693219358/

how-and-why-to-eliminate-the-zero-lower-bound-a for a discussion and links to related blog posts and articles. Accessed September 2015.
} 
central banks the freedom to set policy interest rates below zero percent when necessary.

By strengthening the monetary transmission mechanism, these innovations to the practise of monetary policy directly affect the costs of financial sector exuberance and leverage externalities. They change the trade-offs faced by the macroprudential regulator, and the optimal scope of macroprudential policies. Some macroprudential policies that might have been considered desirable in the presence of a binding zero lower bound on interest rates would not be considered desirable if innovations can be made to eliminate this constraint on monetary policy. Arguably, hosting the FPC within the Bank of England will make coordination between the practise of monetary policy and macroprudential policy more effective, resulting in better management of the trade-offs that exist with any of these policies. However, as we argue below, there are substantive arguments for moving the FPC outside the Bank.

\subsection{Monetary policy targets}

P2. There is little or no need for an inflation-targeting monetary authority to take account of financial factors; financial frictions are largely invariant to the nominal regime. There has been a popular view amongst policymakers and economists that monetary policy ought not to react to financial market variables such as risk premia or some measure of financial disequilibrium. That reflected a sense that identifying financial market 'bubbles' was either impossible and/or unnecessary; impossible as policymakers could not and should not second-guess the market and unnecessary since other variables such as inflation, the money supply or perhaps the output gap would convey more reliable information about the equilibrium level of activity and also because monetary policy was more than up to the job of clearing up after any bubble 
had burst ${ }^{15}$. More specifically, for inflation targeting central banks, the success of the regime as an anchor for medium-term inflation expectations, appears to have persuaded many policymakers not to abandon inflation targeting, or even adjust the inflation target. In the UK, the Government reviewed and updated the monetary policy remit in the 2013 Budget (HM Treasury, 2013a), reaffirming the 2 per cent inflation target while granting additional flexibility to support output growth. The updated monetary policy framework stresses that the macroprudential instruments operated by the FPC are the first line of defence against financial stability risks, while also permitting the monetary policy committee to temporarily respond to financial imbalances in support of the objectives of the FPC (HM Treasury, 2013b, page 23).

This Premise has some support in the academic literature on the interactions between monetary policy targets and leverage externalities. Gilchrist and Leahy (2002) employing the Bernanke, Gertler, and Gilchrist (1999) model found that there was little to be gained in terms of stabilising the economy by conditioning the policy rate on financial variables. More recent analyses come to similar conclusions. Cúrdia and Woodford (2009), using a very different theoretical set up, is more nuanced than Gilchrist and Leahy in its conclusions but does not come down strongly in favour of monetary policy reacting to financial variables. That is partly because of our ignorance of the role of financial variables in the transmssion mechanism of monetary policy and partly due to the role that macroprudential policy ought ultimately to play (as emphasized by Woodford, 2012, page 22). More generally, Woodford (2013) argues that financial wedges do not dent the case for flexible forecast-based inflation targeting.

However, a consensus around Premise 2 has not been formed among academic economists: de Grauwe (2008) and (Faust and Leeper, 2015) argue in favour of a

\footnotetext{
${ }^{15}$ See, for example, Blinder and Reis (2005).
} 
lean against the wind approach, where monetary policy would respond to counter swings in asset prices without explicitly targeting financial variables. Sheedy (2014) and Koenig (2011) have shown that a nominal GDP monetary policy target can outperform inflation targets by helping to reduce leverage externalities. Periods of low income growth would also be periods of high inflation, this high inflation would restore the balance sheets of heavily indebted firms, dampening leverage externalities. ${ }^{16}$

In order to reduce the prevalence and costs of zero lower bound episodes that break the monetary transmission mechanism, bolder changes to monetary policy targets may be required. Blanchard et al. (2010) and Ball (2013) propose raising the target rate of inflation whilst retaining an inflation targeting framework: Higher inflation increases distortions in product and factor markets but it also increases policymakers' room to maneuvre in downturns, reducing the likelihood of zero lower bound episodes. Eggertsson and Woodford (2003) and Nakov (2008) show that a policy of price-level targeting can help reduce the duration of zero lower bound episodes. Under price-level targeting, earlier shortfalls in inflation below target are compensated by future increases in inflation. This raises expectations of inflation during zero lower bound episodes, encouraging increases in investment and consumption that restore the monetary transmission mechanism. ${ }^{17}$

The setting of monetary policy targets has macroprudential consequences. The FPC should consider these proposals (and others) for their prospective macroprudential benefits. Furthermore, the FPC should be involved in any review of monetary policy targets that are motivated by concerns external to

\footnotetext{
${ }^{16}$ Duncan (2015) shows how the choice between nominal output and inflation targeting can affect the incentives of firm managers to choose projects with greater systematic risk, to herd with their competitors.

${ }^{17}$ Hatcher and Minford (2016) review the literature on price-level targeting.
} 
financial stability but that may have macroprudential consequences. At the same time, retaining the Bank of England's dependence on Parliament to set monetary policy targets is a fundamental principle of modern central banking, enhancing accountability and credibility.

\section{Tax policy}

There may be good reasons why firms and households primarily use debt contracts to finance their activities rather than more risk sharing contracts such as equity. Importantly, debt contracts tend to allocate risk with control, dampening the potential for moral hazard. ${ }^{18}$ But the widespread use of debt finance risks exacerbating leverage externalities that amplify business cycles.

In addition to responding to problems of moral hazard, the decision between debt finance and equity finance also responds to the regulatory and tax treatment of these contracts. In most modern economies, the tax treatment of equity finance is disadvantageous relative to debt finance. That bias may amplify the effects of financial volatility on the real economy.

Within the UK, in addition to the differential tax treatment of debt and equity issued by corporate firms, a potentially worrying development is the UK Government's recent reduction in the bank levy, a tax on banks' debt liabilities, and coincident introduction of the bank profit surcharge, a new tax imposed on bank profits. ${ }^{19}$ This tax change further tilts incentives towards debt finance, and against equity finance and may discourage new entrants into the banking sector, none of which obviously appears to constitute enhancing the stability of the financial sector.

\footnotetext{
${ }^{18}$ In a working paper version of the current paper we describe some of the theory behind the widespsread use of debt contracts in finance.

${ }^{19}$ See http://www.bbc.co.uk/news/business-33444127 Accessed August 2015.
} 
Encouraging debt finance through the tax system directly opposes the efforts of the PRA and the FPC to reduce systemic risk, leverage and the implicit taxpayer subsidy of banks. The differential tax treatment of debt and equity should be addressed, and the FPC could have an important role in assessing and communicating the potential risks to financial stability that it poses. It may also be worth noting that in addition to encouraging financial instability, the favourable tax treatment of debt finance actually penalizes regulatory compliance - increasing any potential gains from lobbying, regulatory capture or misreporting.

In the wake of the crisis, officials have made public statements about the negative impact of differential tax treatment of equity and debt for financial stability. Two notable examples are Haldane (2011) and Kocherlakota (2011). But both of these speeches carry the usual disclaimer that the views expressed are not necessarily those of the Bank of England and Federal Reserve respectively. Given the FPC's responsibility for financial stability, the FPC should be given an explicit role to review the effects of current and any proposed tax policies on financial stability, and that the results of these reviews should be made public.

\section{P3. There is little or no need for fiscal policy/tax policy to have} a macroprudential role. Arguments have been made that coordination, expertise and information sharing are all facilitated by having much of the supervisory function located in one institution. Moreover, politicians do not wish to be seen to be meddling overly in regulation and, politically, there may be some cover when crises occur in having other authorities in charge. Together, these arguments help make the case for the lead role of the Bank. ${ }^{20}$

However, the distance between fiscal policy-and politicians-and regulatory policy is rather limited in practice. First, the Chancellor retains much influence

\footnotetext{
${ }^{20}$ The official case is set out more fully by the former Chancellor of the Excehquer, George Osborne, in the course of his his Royal Economic Society Lecture in 2015.
} 
over the tone of regulation via the power of appointment of key individuals. ${ }^{21}$ Second, the Chancellor writes each year to the FPC setting out its priorities. In the past some central bankers have voiced concerns that giving central banks regulatory responsibility could compromise independence. ${ }^{22}$ Whilst there appear to be few commentators concerned that the Bank's independence has been compromised (indeed one hears the opposite criticism), there may be a risk, under the current arrangements, of the FPC's remit extending in ways that may not be optimal. For example, on 8 July 2016 the Chancellor wrote to the FPC noting that the program of reform of the banking system "is close to finalisation" stating that

"....I would like the Committee to consider how, subject to its primary objective to protect and enhance the stability of the UK's financial system, its actions might affect competition and innovation, and their impact on the international competitiveness of the UK financial system."

It is not clear quite what this means but it is at least open to the interpretation that subtle changes in the FPC's objectives are happening. More generally, the statutory aims of the Bank and the FPC are vague and there are no clear medium term objectives. Third, the tax system has many points of contact with the financial system and financial stability. For example, as noted, there is the role of the tax system discouraging equity in preference to debt in corporate financial

\footnotetext{
${ }^{21}$ For example, Martin Wheatley of the Financial Conduct Authority recently resigned after being told by the Chancellor that his contract would not be renewed. According to some reports he fell from political favour in part because of an over-zelous approach to regulation.

${ }^{22}$ For example, ex-Bundesbank chief Axel Weber, who currently chairs Swiss group UBS, said he "flatly refused" to take on a regulatory remit when he was head of the bank due to concerns over independence. http://www.theguardian.com/business/2013/mar/31/bank-ofengland-powerful-central-bank
} 
policy. Many economists have pointed to the part that property lending played in the recent and in previous financial crises. No doubt many supply and demand side factors are in operation but the role of land and housing tax undoubtedly plays a part as do enduring planning issues. ${ }^{23}$. There is, most obviously, the taxation of banks in particular the bank levy and the bank corporation surcharge tax. And, of course, there is the impact of future expected bailouts.

Many of the problems associated with financial crises including collateral fire sales and the amplification of shocks through leverage externalities have little to do with money and central banks per se. And monetary policy may be of lesser importance than the role of regulatory and tax policy interventions in internalising the social cost of financial volatility.

So, the problem with Premise 3 is that fiscal policy already connects to issues of financial stability at many points, but does so in an uncoordinated way which is prone to political pressures. In addition, a number of financial frictions are not monetary in nature and may be better addressed through mechanisms that are not necessarily in the power or purview of the Bank. Moreover, as a number of analysts have argued, political preferences also influence the likelihood of bailouts.

\subsection{Real time coordination with tax policy}

The FPC has recently been granted the powers to impose restrictions on mortgage lending. Specifically, these restrictions would limit the loan-to-value (LTV) and/or debt-to-income (DTI) ratios of new mortgage loans. ${ }^{24}$ These restrictions are intended to dampen the growth of high risk mortgage loans, but they come at

\footnotetext{
${ }^{23}$ The current tax treatment in the UK of income and capital gains creates a bias against the rental market in favour of owner-occupation. Moreover, many analysts have proposed shifting to a land value tax in part to address the costs of land lying undeveloped for long periods of time. How the existing tax system interacts with current and proposed financial regulation on property lending is an important, and under-researched topic. See also Muellbauer (2012).

${ }^{24}$ http://www.legislation.gov.uk/uksi/2015/909/pdfs/uksi_20150909_en.pdf
} 
the cost of preventing many families from purchasing their first home.

This enabling act followed the introduction of the UK Government's Help to Buy equity loan programme, which involved the government taking a risksharing stake in high LTV mortgage loans, and the Help to Buy individual savings account programme, which provided favourable tax treatment for households saving towards a mortgage deposit. ${ }^{25}$

It is not clear that there has been an intention to coordinate these two interventions, although it is interesting to note that a similar (still possibly unintended) coordination of tax and regulatory policies has occurred in New Zealand, where the recent tightening of LTV ratio limits coincided with the relaxation of rules governing the use of tax shielded savings toward mortgage deposits. ${ }^{26}$ Whether or not coordination was intended in these specific cases, it is worth outlining some of the costs and benefits of coordination of macroprudential policies with tax policy interventions.

The main benefit associated with coordination of macroprudential policy with tax policy is that it is possible (in theory) to design the combined intervention to be distribution-neutral. The regulatory interventions described above, restricting lending primarily to first home buyers, have clear distributional consequences against these households, and the tax interventions described above dampen the costs of these restrictions suffered by these first home buyers, reducing the distributional effects of the policy.

\footnotetext{
${ }^{25}$ Details are available at https://www.gov.uk/affordable-home-ownership-schemes/help-to-buy-equity-loans for the Help to Buy equity loans and https://www.gov.uk/government/uploads/system/uploads/attachment_data/file/413899/ Help_to_Buy_ISA_Guidance.pdf for the Help to Buy individual savings account scheme. Accessed 21 August 2015.

${ }^{26}$ See http://www.stuff.co.nz/business/industries/68502913/ Reserve-Banks-new-loan-restrictions-for-Auckland-property-investors and http://www.stuff.co.nz/business/71371470/ first-home-buyers-applying-for-government-grants-doubles (Accessed August 2015)
} 
Offsetting the distributional consequences of macroprudential policy could be desirable if these conflict with the wider aims of the Government. But it also suppresses legitimacy concerns that could arise from policy interventions that clearly harm particular groups of households. The media and the public currently appear to be tolerant of macroprudential regulation, but this could quickly change if these regulations appear to punish or favour specific groups, and in particular when memories of the global financial crisis fade ${ }^{27}$.

One reason to think that the public's tolerance of these types of intervention might fade in future is that the relevant externality is difficult to communicate. In the case of LTV and DTI limits, these are restrictions on loans associated with pecuniary externalities. Implementing policies that prevent young families from moving into their first home while reducing the value of properties owned by retirees are not always going to be welcomed.

There are, however, also reasons to be concerned about the coordination of temporary macroprudential policies with targeted subsidies. In practise, it can be very difficult to design policy bundles that have the desired distributional and efficiency consequences. In the case of Help to Buy equity loans, there is a clear moral hazard problem. The risk sharing involved means that if the property is sold before the home equity loan is repaid, increases or decreases in the sale price are shared with the Government. There are likely to be situations when value enhancing repairs or improvements are foregone by current owners who know they will pay the full cost of these improvements but will share the benefits with the Government.

Actual or perceived coordination with tax policy also risks the independence of the regulator. For instance, if the regulator is believed to have acquiesced to

\footnotetext{
${ }^{27}$ Senior policymakers have muted concerns. See (Large, 2013) and (Tyrie, 2013). Sir Andrew Tyrie, according to press reports, reiterated some of these concerns at a 2017 Bank of England conference to mark 20 years of Bank independence.
} 
political demands trust amongst the population could quickly plummet and the regulator might quickly find itself in a highly politicized position.

A further risk is that for political reasons, the subsidy interventions might not be lifted when the macroprudential restrictions are lifted. That could mean that the lifting of restrictions would still have distributional consequences, as would the re-imposition of restrictions in future. The upshot might be that a possibly poorly designed subsidy intervention could remain in place indefinitely.

Consequently, the costs associated with the coordination of time-varying macroprudential policy interventions with tax policy may well be greater than the benefits. In the case of mortgage LTV and DTI restrictions, the FPC should seek to use permanent, rather than temporary restrictions. That would reduce the costs of seeking future changes to these restrictions, which we think could expose the FPC to future political challenges whilst doing little to enhance financial stability. The motivation for these policies is to ensure that lending standards are do not loosen excessively during boom times (FPC, 2014), when these regulatory restrictions are likely to be binding. During downturns, market lending standards are tight (e.g., Bassett et al., 2014), and regulatory restrictions are unlikely to bind. Relaxing regulatory lending standards during these periods would likely have little impact on lending behaviour.

\section{Too big to fail}

P4. Ending universal banking, increased capital requirements and overhauled recovery and resolution are the key to ending TBTF. TBTF has been a dominant theme since the crisis unfolded in 2007, although it has been an issue for many years. The policy consensus that appears to have emerged is that systemically important institutions should be discouraged but nevertheless allowed 
to exist as long as they can be "resolved" 28 . Specifically, the policy response to TBTF has been multi-pronged via (proposed) increases in capital and liquidity requirements via Basel III (CRDIV), Global Systemically Important Bank (GSIB) capital surcharges, Pillar 2 increases and resolution-related capital buffers. In addition to these, in the UK there has also been structural reform (following the Vickers ring-fencing proposals). Some politicians and regulators appear to believe we are now close to solving the TBTF problem and that reforms to resolution have been key to this (Cunliffe, 2014) ${ }^{29,30}$.

The progress on agreed resolution procedures does indeed appear impressive in so short a period of time. The proposed resolution procedures essentially entail major reforms to bankruptcy procedures of banks and have been agreed across countries to a specification set out by the Financial Stability Board (FSB), an international group of finance ministries and central banks that makes broad recommendations to member states on issues relating to systemic risk. Banking groups will draw up and implement plans that show how they will recover from difficulties or be resolved in the event that recovery is infeasible as determined by the national Resolution Authority (the Bank of England in the case of the UK). At that point, equity holders may be wiped out, followed by debt holders of various stripes (excluding, amongst others, insured depositors) until losses are accounted for. The remaining debt holders may now be the proud new owners of a bank. The required amount of Gone Concern Loss Absorbing Capacity (GLAC) - the debt that may be bailed in upon resolution-remains contentious. ${ }^{31}$ Importantly, the

\footnotetext{
${ }^{28}$ It appears that the Bank, as resolution authority, will decide when the regulated firm's resoltion plan is adequate.

${ }^{29}$ Cunliffe notes that "Some key...[reforms]...remain to be agreed. Particularly important here are the remaining reforms on resolution that, when taken together with what has already been achieved, will mean that we will finally be able to say with confidence that no bank is too big to fail." Page 10.

${ }^{30}$ Others earlier have expressed doubts. See Haldane (2012).

${ }^{31}$ More generally, GLAC refers to long term debt that is subordinated to deposits, secured
} 
resolution needs to be done in such a way as not to compromise the key functions of the bank or the rest of the financial system.

Thus progress seems to have been made: there is more and better capital and liquidity in the banking sector; GSIBs have been identified and will be supervised more stringently; a roadmap, agreed across countries, has been approved on how to resolve these banks in case of trouble. But has the TBTF problem really been solved?

The majority of substantive changes in these regulations are intended specifically to make banks safer. Other things constant, that may be so. But, other things are not constant. The banking sector across many jurisdictions has become more concentrated since the financial crisis, partly as a result of bank bailouts. Governments and central banks were observed to have bailed out more than just banks and guarantee liabilities much wider than those covered by deposit protection schemes. Many of the risks realised during the financial crisis were in any case not directly related to the regulated banking sector. And as a result of changes in prudential rules many of the risks that were 'contained' within the regulated banking sector may migrate to less regulated areas of the financial system. ${ }^{32}$

In addition, if a large bank needs to be resolved, experience suggests that

debt and other senior liabilities. This includes Contingent-Convertible bonds (Co-cos) which convert into equity in response to triggers relating to equity ratios. The term "Gone" might be slightly confusing as the main priority of the new bank resolution infrastructure is to keep banks "Going" as they recapitalise through the restructuring of any GLAC liabilities.

${ }^{32}$ It is difficult to find direct evidence that this is so at the moment. One piece of anecdotal, and indirect, evidence may be this: According to recent research, Wright (2015), pay at investment banking firms has decreased markedly since the financial crisis. Compensation cost per employee at global investment banks fell 25 per cent from 2006 to 2014. In aggregate, pay has fallen from roughly half of revenues at investment banks in the five years before the crisis to about 40 per cent since. On the other hand, average compensation cost per employee at global asset managers rose 22 per cent. These trends have coincided with anecdotal evidence of staff leaving investment banking for the asset management industry. 
it will not be alone and a number of other institutions are likely to be in trouble simultaneously. The question is, during such a period when liquidity and solvency difficulties become indistinct, will the Resolution Authority-The Bank-really be able to conclude that recovery is not feasible across a number of (doubtless interlinked) institutions and markets and hence that they should each be resolved and indeed can be resolved such that there is no disruption to the rest of the financial system? Will the political climate permit losing a major bank or two when other countries may be supporting their major institutions? Might not a case - political or not - then likely be made that any attempt at resolution is unnecessary, impracticable and in any case dangerous in terms of wider financial stability? Will the legal process of resolution across countries operate smoothly? ${ }^{33}$ The new resolution regime may simply boil down to a statecontingent commitment finally to break up banks in likely turbulent economic times during febrile financial market conditions. But how fundamentally different is that to the situation before the recent crisis? How much have these reforms changed the incentives facing shareholders and debt-holders in any bank? If banks need to be broken up in difficult times then one might wish to argue they ought to be broken up now. ${ }^{34}$

There are arguments that breaking up banks into smaller units may neither be desirable nor feasible. Damjanovic, Damjanovic, and Nolan (2013) outline a macro-banking model whereby a trade-off exists between larger universal banks

\footnotetext{
${ }^{33}$ There are some indications that complications could well arise. http://corpgov.law.harvard.edu/2015/09/06/england-andgermany-limit-bank-resolution-obligations/

${ }^{34}$ In the US the Fed's future discretion to intervene appears curtailed: indeed, some argue that state bailouts are prohibited under Title II of Dodd-Frank. Whether such a commitment will endure during a systemic crisis is an open question, of course. And Calomiris and Haber (2014, p. 278) argue that Dodd-Frank simply codifies when intervention will occur: ex ante it appears stringent but ex post there is enough wiggle-room in the legislation such that, in their opinion, it ultimately exacerbates the TBTF problem.
} 
which lend more, crash relatively frequently and at greater cost to the taxpayer, versus a smaller, less risky and more profitable banking sector (split between retail and investment banks) that lends less, crashes less frequently but at less cost to the taxpayer, but may be more resilient to certain types of shocks. The welfare judgment turns on a complicated set of trade-offs involving the relative magnitude of general or systemic-type financial shocks and pre-existing distortions in the economy. If the economy is quite distorted (and hence has a low "natural rate of output'), and financial shocks are not too large, then universal banks may be preferable as they offset low average output. On the other hand, the banking sector can be too big when dominated by universal banks. It is difficult to judge which version of the model is empirically more applicable.

Some have argued that returns to scale in banking are larger than traditional analyses suggest (although it is hard to control for implicit bail out subsidies). Banks themselves tend to argue that size and universality brings benefits in terms of risk-smoothing and economies of scope. Others (e.g., Basu and Dixit, 2014) have pointed out that breaking banks up may be costly and futile from a regulatory point of view as it is difficult to levy penalties on small competitive banks with limited liability. If lots of smaller banks adopted correlated investment strategies and were less profitable than a smaller number of bigger banks, then it could well be that financial crisis would be harder to deal with than under the status quo (Chari and Phelan, 2014, Duncan, 2015 and Farhi and Tirole, 2012 present models of the interaction between financial sector herding and stabilization policies). Finally, it has been argued that the existence of big banks is ultimately a political decision; they may be seen as 'national champions' individually or collectively and as a good source of tax revenue in tranquil times. On this view, TBTF will end when politicians decide it will end. The existence of big banks and their political 
influence is documented in a recent book ${ }^{35}$ through history and across various countries.

It is difficult to know if we have really solved the TBTF problem. It seems that progress is being made. But the banking sector remains concentrated, as do other segments of the financial sector ${ }^{36}$. Moreover, even if banks were broken up correlated risk strategies could still entail a collective TBTF problem. Perhaps a more fruitful approach is to define ex ante how the authorities will act ex post, having bailed out an institution. Whilst shareholders are typically wiped out, one notes that few bank executives have suffered as a result of their institutions receiving taxpayers money. In particular, and as a result, remuneration schemes internal to banks did not attenuate the moral hazard problem. Nolan, Sakellaris, and Tsoukalas (2015) argue that it seems unlikely that the authorities could ever commit not to bailout some institutions in at least some circumstances. They therefore suggest that one way to reduce the moral hazard risk is to ensure that there is commitment to penalize senior management and shareholders in the event of a bailout. Such a proposal is clearly both complex and controversial and would go much further than the current proposals on the table.

We suggest that it is prudent to assume that the TBTF (or the too correlated to fail) problem has not been solved. It may be wise for regulators to consider what mechanisms and penalties they might commit to now that would reduce the likelihood of future bailouts. Such mechanisms should, of course, be publicly known. However, given that the Bank of England is the resolution authority for the UK, to what extent might the FPC be able to question the effectiveness of the new resolution regime and raise legitimate concerns that TBTF may remain

\footnotetext{
${ }^{35}$ Calomiris and Haber (2014)

${ }^{36}$ Notably asset management about which less is known but concern is present. http://financialresearch.gov/reports/files/ofr_asset_management_and_financial_stability.pdf, See Chapter 3: http://www.imf.org/external/pubs/ft/gfsr/2015/01/pdf/text.pdf.
} 
an existential threat to financial stability and perhaps the public finances? We take up this issue below.

\section{Governance concerns}

Concern over the structure (and size) of banker compensation packages appears to be well justified. A widespread view is that senior bankers have been willing to exploit previously held trust or reputation for short term gains in the years preceding and in the wake of the Great Recession. In a business where the gains from trust are high, its erosion surely carries significant costs for the economy going forward. ${ }^{37}$

It is unsurprising, therefore, that regulators have expressed concern about bankers' compensation contracts and any incentives contained therein to bring forward profits at the expense of long term profitability. But, these concerns should be shared by shareholders. Ideally, shareholders and regulators would agree completely on the design of bank compensation contracts, the extent to which rewards should respond to bank share performance as well as other metrics, and the extent to which these rewards are sensitive to short versus long term bank performance.

Sharp disagreement over the design of compensation contracts is likely to be a reflection of poor bank regulation failing to internalize the costs of bank failure, encouraging shareholders through their director proxies to design compensation contracts in such a way as to encourage excessive risk taking, safe in the knowledge that potential losses will be partly or fully absorbed by the taxpayer. To the extent that this is the case, any regulations targeting banker compensation structures are

\footnotetext{
${ }^{37}$ Examples of disreputable actions span both the retail and wholesale businesses of UK banks, including (but not limited to) the mis-selling of payment protection insurance and interest rate derivative contracts to retail and commercial customers, as well as the manipulation of LIBOR benchmark interest rates and foreign exchange rates.
} 
likely to be subverted. Bonuses will be replaced by "allowances".

But the picture might be more complicated. A firm that is sufficiently capitalised to withstand risks in the near term may still face serious risk of default or dilution in the longer term, and this risk could have the effect of increasing the effective discount rate of shareholders, making them more focused on short term profits at the expense of long term rewards they are not certain of enjoying.

It is also possible that the alignment of bank shareholder incentives with the interests of the broader economy will not ensure efficient bank actions if shareholder governance structures are weak. That could be a reflection of inefficient financial structures, or the result of broader problems with current corporate governance regulations, the effects of which are likely to be amplified in the financial sector where risks can be well hidden.

Banks' financial structures are influenced greatly by (microprudential) regulators rather than solely by market forces and competition. It may be the case that leverage and liquidity requirements that are just sufficient to ensure bank solvency throughout the credit cycle or 'stress test' are not consistent with the optimal financial structures that would best align the incentives of shareholders with the broader economy, and also allow shareholders effectively to pass on these incentives to directors and executives. In any case, it is clearly disturbing to see how much damage has been inflicted on bank reputations in the UK in recent years, and it is important to consider what if any effect the regulatory environment has on the incentives for bank shareholders to build their own firms' reputations for the long run. However, as noted at the end of the previous section, given that the Bank of England is the core of the microprudential framework in the UK, how able is the FPC to critique that framework (including, for example, the Senior managers Regime) from a wider financial stability perspective? 


\section{An effective and legitimate macroprudential authority}

Ideally, the macroprudential regulator would be an omniscient, omnipotent and benevolent dictator. In practise, omniscience is limited by the environment, and the remaining two are determined by the political process. The extent to which the macroprudential regulator can act quickly and unilaterally with their instruments (dictatorship) is sustained by the regulator's legitimacy, which must be protected by limiting the powers of the regulator (removing their omnipotence) and assigning the regulator with clear intermediate policy targets. These intermediate policy targets must be consistent with the wider policy goals, ensuring the stability and efficiency of the financial system. But these policy targets must also be objectively verifiable in reasonable time, such that the public can effectively monitor the current regulator. In practise, it is likely that these intermediate targets will differ markedly from what we would consider consistent with broader efficiency concerns. That is, they will not coincide perfectly with a broad mandate for benevolence.

Macroprudential policy poses some unique and challenging problems for institutional design. Taking these problems seriously will be an important determinant of the legitimacy of macroprudential regulators, and in generating support for macroprudential regulator required to implement improvements in policy to promote the stability and efficiency of the financial system. The political problem of legitimacy is inseparable from the technical problem of optimal policy.

\section{Limited understanding}

Economists have not reached consensus over the mechanisms underlying financial crises and the financial amplification of business cycles. This limited understanding of financial crises undermines both the effectiveness of the macroprudential regulator and their legitimacy. 
There is broad consensus that information asymmetries between borrowers and lenders prevent sharing of individual specific risks. ${ }^{38}$ That encourages debtlike contractual relationships over equity, and the prevalence of debt finance concentrates the losses of business cycles on debtors. This concentration of losses encourages fire sales and bankruptcies, amplifying business cycles.

However, while it is clear that information asymmetries should prevent the efficient sharing of individual specific risks, it is not clear why these information asymmetries should prevent the efficient sharing of macroeconomic risks. In the canonical financial amplification models of Bernanke, Gertler, and Gilchrist (1999) and Kiyotaki and Moore (1997), households and firms are prevented from sharing macroeconomic risks by assumption. Introducing macro risk markets largely removes financial amplification from these models. ${ }^{39}$ In response to this result, many authors have concluded that these macro risk markets must be currently closed. If we accept that conclusion, there are a wide variety of policy and market based solutions including regulation or Pigouvian taxation (Jeanne and Korinek, 2010); changes to monetary policy rules (Sheedy (2014) and Koenig (2011)) and linking mortgage and bank deposit contracts to macroeconomic outcomes (Mian and Sufi (2015), Shiller (2008), Cochrane (2014), Goodhart (1988, Ch. 7)). But this conclusion has been challenged by Duncan and Nolan (2016). They show that financial amplification is consistent with the privately optimal sharing of macro risks. Macro risk markets might not be "missing".

There is also no consensus over the likelihood of crises or volatility of leverage and credit spreads that would prevail in an efficiently working economy. A related problem is that economists have not reached consensus over reliable objective measures of financial sector risk that could be used to design intermediate targets

\footnotetext{
${ }^{38}$ See for example Townsend (1979) , Gale and Hellwig (1985), Krasa and Villamil (2000) and Duncan and Nolan (2014).

${ }^{39}$ See Carlstrom, Fuerst, and Paustian (2014), Krishnamurthy (2003) and Nikolov (2014).
} 
for regulators against which their effectiveness can be determined in reasonable time. One may sense that the current FPC is doing a good job, but there really is no objective way to know.

That marks a clear distinction between macroprudential policy and other areas of regulation or policy delegated to independent authorities. In the case of monetary policy, there is broad consensus that inflation targeting is reasonably consistent with efficient aggregate demand management, and we can and do judge the effectiveness of the Bank of England by the extent to which inflation outcomes are consistent with the inflation target. In the case of utility regulation, benchmarking regulated prices against peer countries is one of a number of straightforward ways an outside observer can check the performance of the regulator. But it is more difficult to arrive at objective ways to monitor the performance of the macroprudential regulator.

\section{Legitimacy, instruments and targets}

Since there are no clear and objective targets for macroprudential regulators, any arrangement seen as legitimate will be one with restricted powers. That is problematic. Unlike the case of monetary policy, where there is consensus that Bank Rate is a necessary and sufficient instrument in normal times, macroprudential policy in theory could employ many instruments. Illegitimacy concerns could be amplified if regulators are seen to have close links to the financial sector and at the same time propose regulations or tax changes that are perceived likely to worsen the distribution of wealth and/or income.

While the FPC appears to have permission to comment broadly on all policy areas including tax policy, there is a reluctance to make public statements concerning the implications of current tax policies for financial stability. Specific examples include the bank levy, and the tax treatment of equity relative to debt 
finance which both have the effect of discouraging equity finance and increasing financial sector leverage. Indeed, to do so may breach the FPC's legal requirement to support the economic policy of the Government. This example highlights the lack of instruments that the FPC has access to in practise.

In sum, it is hard to find a parallel to macroprudential policy in terms of the powers that are delegated, the difficulties in communicating how policies are likely to meet objectives, and the difficulties in determining even ex post whether or not the regulator has achieved, or indeed is able to achieve, their goals of ensuring financial stability.

\section{Discussion and conclusions}

Some commentators suggest that the recent financial crisis resulted from a toxic mix of circumstances whilst others argue that the financial sector is inherently unstable. Either way, and acting proportionately in the meanwhile, policymakerspoliticians and regulators-need to be prepared for a possible recurrence. If, as argued in this paper, macroprudential oversight is necessarily a wide-ranging activity the current remit of the FPC is too narrow. Its remit should cut across a number of other bodies' areas of responsibilities and expertise. Not only are the policies of the Prudential Regulatory Authority and the Financial Conduct Authority of direct interest (bodies already represented on the FPC) but so too might others. For example, the Competitions and Markets Authority and the Financial Reporting Council (soon to be replaced by the The Audit, Reporting and Governance Authority) might be involved as issues of market conduct and accounting practices have been implicated in aspects of the recent crisis. Similarly, economic research has raised possible empirical links between sovereign indebtedness and wider financial stability. The Office for Budget responsibility routinely assess fiscal sustainability and would be well-placed to advise on those 
issues. Related, the Institute of Fiscal Studies and similar professional bodies may be drawn upon to advise on tax-related issues of concern to financial stability. And there are doubtless roles for other stakeholders. However, that potential widening of the players involved in macroprudential oversight clearly raises tensions within the current remit of the FPC and given its location in the Bank of England.

In questioning Premises 1.-5., we concluded that macroprudential concerns cover many areas not typically within the scope of central bank expertise and/or that cut across overtly political terrain. Related to that is a risk that the macroprudential import of some issues (e.g., TBTF, financial sector salary structure, dividend payout policy) is downplayed unduly in the Bank's formal assessments of extant risks to financial stability, as the Bank perceives itself to have dealt with those issues. All this raises a central tension, as we see it, between the current overly narrow scope of UK macroprudential policy and an expanded role for the Bank of England that would necessarily exacerbate questions around legitimacy and potentially lead them to critique areas of Government policy perhaps contravening their current legal mandate.

If these concerns are well founded, what reforms to the FPC and how it functions might be desirable? The danger surely exists of constructing a rulebook of no slight complexity, questionable legitimacy and little enduring value. So, we conclude with a series of recommendations that emerge from our analysis. Our overarching view is of the role of the FPC is as an independent body charged with assessing the efficiency and stability of the financial sector and informing publicly all aspects of policy that affect that efficiency and stability.

\subsection{Institutional recommendations}

1. Macroprudential policy is about more than ensuring the effectiveness of monetary policy in crisis periods. Macroprudential policy has a wider 
concern for the efficiency and stability of the financial sector. Therefore, in addition to its responsibility to enhance financial stability, the FPC should be made responsible for assessing the efficiency of the financial sector in the UK.

2. Macroprudential oversight may not be best situated in the Bank of England. The composition of such an oversight body should reflect expertise on tax, accounting, law, corporate governance and other areas. Macroprudential actions have consequences for the distributions of wealth and income and that should be reflected in any associated decision-making powers.

3. That financial efficiency assessment should generate policy recommendations for other areas of public policy. For example, the FPC should be required to comment on any area of policy (public or private) which may damage efficiency or exacerbate financial stability (e.g., tax policies that increase leverage, housing, planning or land use policies, the incentive structure of private sector pay, distortions in accessing bank or equity finance for SMEs, etc.).

4. Policymakers should design a set of intermediate targets against which the FPC can be judged. These intermediate targets are likely to be updated as time passes. More research needs to be done to clarify how the assessment of financial efficiency and the goals of the macroprudential regulator can be linked to clear objective targets.

5. The FPC should seek to distance itself, where possible, from political decisions. The coordination between macroprudential regulations and tax interventions aimed at alleviating the distributional consequences of certain policies may be desirable in certain circumstances, but carries significant 
costs in terms of independence, unintended consequences of poor policy design and increased complexity of the tax code.

6. Monetary policy regimes (for example inflation, nominal GDP or broad money growth targeting) have consequences for financial stability and consequently should be scrutinized by the macroprudential regulator particularly as to their effectiveness in crisis periods.

7. The current 'comply or explain' powers held by the FPC probably strike a useful compromise by removing the ability for the FPC to act unilaterally while allowing it to comment on a wide range of policy areas. These powers should be used assertively to intervene authoritatively in, and generate, important policy debates.

How practicable are the suggestions we have made for a more influential and independent FPC? Indeed, such a suggestion raises many difficult issues. To understand some of those difficulties we can do no better than repeat some of the questions a referee raised with us:

How will the institutional design and accountability of a reformed FPC avoid political influence? Where should members be recruited from and how? Who decides the boundary of what is 'in scope' and what is not? Should it report to Parliament and be funded by Parliament? Should it have an advisory role like the Committee on Climate Change or should Government policy be directly informed by it like the OBR? How many times should it meet? Should it, for example, offer an insight after each Budget, MPC meeting or opening of Parliament? Should it comment on all political parties' policies prior to elections? Should it offer specific policy recommendations 
or more general comments; e.g., [recommending] the government [...]

raise stamp duty versus [...] cool an overheating housing market?

Before the Bank of England was granted independence in respect of monetary policy, a long-running and evidenced-based debate took place within academia and wider political and policy circles. It was in many ways an idea whose time had come. Experience with macroprudential policy is in its relative infancy and no doubt experience from the UK, overseas and academic research will yield valuable insights in the years ahead. But as we have tried to argue, even now issues of concern are emerging.

The most important elements in our proposed framework is for the FPC to be independent of Government and Bank; to decide its own areas of interest; to be comprised of experts in areas of necessary expertise and to be directly responsible to Parliament. It could well be that the potentially wide-ranging remit of our propose FPC would make its Chairperson akin to the the Comptroller and Auditor General, and so should be an Officer of the House of Commons; or, perhaps a statutory governance structure as with the Committee on Climate Change would be sufficient. What is key, is that following an appropriate and wide-ranging consultation, the FPC should be headed up by an independent-minded individual able to shape the governance structure as she or he sees fit to achieve its aims and objectives.

\section{Appendix: Brief overview of macroprudential policy}

As we noted in the main text, the main justification for micro-prudential policies is based on the idea that if the costs of bank failure are passed on to taxpayers whilst the benefits of bank risk remain private, then banks are likely to be excessively risky from a public perspective. 
Within the United Kingdom, microprudential regulation is developed and implemented by the Prudential Regulation Authority (PRA). The principles underlying microprudential regulation have been updated recently by the Basel Committee on Banking Supervision (BCBS) of the Bank for International Settlements (BIS). These "Core Principles", considered "universally applicable", are divided into two sets (BIS, 2012, page 9). The first set comprise, in broad terms, the duties, functions and powers of supervisors, whilst the second focus on prudential regulations and requirements for banks.

The Core Principles consciously do not include a specific stand-alone Core Principle on macroprudential issues although regulators and banks are encouraged to take the macro environment into account. They recognize that macro risks, including those that may flow from macroeconomic policy and indeed macroprudential regulation, are present and assert that "[S]ound macroeconomic policies (mainly fiscal and monetary policies) are the foundation of a stable financial system."

On the other hand, IMF analysis argues: "Financial stability need not...emerge as a natural by-product of an appropriate macroeconomic policy mix. Rather, achieving the objective of financial stability requires dedicated macroprudential policies." (IMF, 2013, page 5)

The concerns of macroprudential policy are perhaps slightly more difficult to define and identify. Essentially, macroprudential policies are concerned with the actions of many institutions/lenders/borrowers who individually may be acting prudently, but whose actions in concert may be imposing costs on others and compromising the effectiveness of monetary and fiscal policy. For example the IMF (2013, page 6) states that "The rationale for macroprudential intervention rests on the presence of three sets of systemic externalities. These arise through: (i) the tendency of the financial system to amplify adverse aggregate shocks; (ii) macro- 
financial feedback mechanisms that result in an overexposure to such adverse aggregate shocks; and (iii) linkages within the financial system that increase the vulnerability of the system to idiosyncratic or aggregate shocks." 40

There is an important difference in the concerns that motivate macroprudential and microprudential regulations. Microprudential regulation aims to internalize the direct cost to taxpayers associated with implicit or explicit guarantees of financial institutions' liabilities whereas macroprudential regulation aims to internalize externalities that emerge through the price system, amplifying financial sector volatility, even when there are no direct taxpayer funds at stake. Nevertheless, in practice the instruments of macroprudential management are largely familiar:

"Macroprudential policy uses primarily prudential tools to achieve its objectives. This can include countercyclical capital buffers and provisions, sectoral capital requirements, measures to contain liquidity and foreign exchange (FX) mismatches, and caps on loan-to-value (LTV) and debt-to-income (DTI) ratios. Macroprudential policy can also seek to affect the design of products offered to borrowers in retail markets, and the functioning and institutional underpinnings of wholesale markets. It can finally seek to use tools that are traditionally associated with other policy fields, such as monetary (e.g., reserves requirements), fiscal (e.g., levies imposed on wholesale funding) and competition policy (e.g., takeover policies)" (IMF, 2013, pages 7-8).

\footnotetext{
${ }^{40}$ Broadly speaking the IMF's first two externalities map into our first two externalities. The third externality here is reflected in our third and fourth externalities. We found it useful to distinguish between TBTF and herding when thinking about financial linkages and aggregate vulnerability as more policy effort has been directed at the TBTF problem as we discuss below.
} 


\section{References}

Anat Admati and Martin Hellwig. The Bankers' New Clothes. Princeton University Press, Princeton, NJ, 2013.

David Aikman, Jonathan Bridges, Anil Kashyap, and Caspar Siegert. Would Macroprudential Regulation Have Prevented the Last Crisis? Journal of Economic Perspectives, 33(1):107-130, Winter 2019.

Laurence Ball. The case for four percent inflation. Central Bank Review, 13(2): 17-31, 2013.

William F. Bassett, Mary Beth Chosak, John Driscoll, and Egon Zakrajsek. Changes in bank lending standards and the macroeconomy. Journal of Monetary Economics, 62(C):23-40, 2014.

Kaushik Basu and Avinash Dixit. Too small to regulate. Policy Research Working Paper Series 6860, The World Bank, 2014.

Ben Bernanke and Mark Gertler. Agency Costs, Net Worth, and Business Fluctuations. American Economic Review, 79(1):14-31, March 1989.

Ben S. Bernanke, Mark L. Gertler, and Simon Gilchrist. The financial accelerator in a quantitative business cycle framework. In J. B. Taylor and M. Woodford, editors, Handbook of Macroeconomics, volume 1, Part C, chapter 21, pages 1341-1393. Elsevier, 1 edition, 1999.

BIS. Core principles for effective banking supervision, September 2012. URL http://www.bis.org/publ/bcbs230.htm. Basel Committee on Banking Supervision review for the Bank for International Settlements. Accessed August 2015 . 
Olivier Blanchard, Giovanni Dell'Ariccia, and Paolo Mauro. Rethinking macroeconomic policy. IMF Staff Position Notes 2010/03, International Monetary Fund, 2010.

Alan Blinder and Ricardo Reis. Understanding the greenspan standard. Proceedings - Economic Policy Symposium - Jackson Hole, (Aug):11-96, 2005.

Willem Buiter. Negative nominal interest rates: Three ways to overcome the zero lower bound. The North American Journal of Economics and Finance, 20(3): 213-238, 2009.

Charles W. Calomiris and Stephen H. Haber. Fragile by Design: The Political Origins of Banking Crises and Scarce Credit, volume 1. Princeton University Press, 1 edition, 2014.

Charles T. Carlstrom, Timothy S. Fuerst, and Matthius Paustian. Optimal Contracts, Aggregate Risk, and the Financial Accelerator. Working Paper 1420, Federal Reserve Bank of Cleveland, October 2014.

V. V. Chari and Christopher Phelan. Too Correlated to Fail. Economic Policy Paper 14-3, Federal Reserve Bank of Minneapolis, July 2014.

Lawrence J. Christiano, Roberto Motto, and Massimo Rostagno. Risk Shocks. American Economic Review, 104(1):27-65, January 2014.

Lawrence J. Christiano, Martin Eichenbaum, and Mathias Trabandt. Understanding the great recession. American Economic Journal: Macroeconomics, 7(1):110-67, 2015.

John H. Cochrane. Toward a Run-free Financial System. In Martin Neil Baily and John B. Taylor, editors, Across the Great Divide: New Perspectives on 
the Financial Crisis, Book Chapters, chapter 10. Hoover Institution, Stanford University, 2014.

Sir John Cunliffe. Ending too big to fail - progress to date and remaining issues, May 2014. Speech given at the Barclays European Bank Capital Summit, London.

Sir John Cunliffe. Macroprudential policy: from tiberius to crockett and beyond, July 2015. Speech given at TheCityUK, London.

Vasco Cúrdia and Michael Woodford. Credit spreads and monetary policy. NBER Working Papers 15289, National Bureau of Economic Research, Inc, 2009.

Tatiana Damjanovic, Vladislav Damjanovic, and Charles Nolan. Universal vs separated banking with deposit insurance in a macro model. Technical report, 2013.

Paul de Grauwe. There is more to central banking than inflation targeting. In Andrew Felton and Carmen M. Reinhart, editors, The First Global Financial Crisis of the 21st Century. VoxEU.Org books. Centre for Economic Policy Research, 2008.

Avinash Dixit. The Making of Economic Policy: A Transaction Cost Politics Perspective, volume 1. The MIT Press, 1 edition, 1998.

Alfred Duncan. Monetary Policy and Herding. Mimeo, August 2015.

Alfred Duncan and Charles Nolan. Disputes, Debt and Equity. Discussion Paper 2014-21, Adam Smith Business School, University of Glasgow, December 2014.

Alfred Duncan and Charles Nolan. Financial Macroeconomics with Complete Business Cycle Risk Markets. Mimeo, August 2016. 
Gauti Eggertsson and Michael Woodford. The zero bound on interest rates and optimal monetary policy. Brookings Papers on Economic Activity, 34(1):139$235,2003$.

Emmanuel Farhi and Jean Tirole. Collective Moral Hazard, Maturity Mismatch, and Systemic Bailouts. American Economic Review, 102(1):60-93, February 2012.

Emmanuel Farhi and Ivan Werning. A Theory of Macroprudential Policies in the Presence of Nominal Rigidities. NBER Working Papers 19313, National Bureau of Economic Research, Inc, August 2013.

Jon Faust and Eric Leeper. The myth of normal: The bumpy story of inflation and monetary policy, August 2015.

Irving Fisher. The debt-deflation theory of great depressions. Econometrica, 1(4): 337-357, October 1933.

FPC. Financial policy committee statement, September 2014. URL http://www. bankofengland.co.uk/financialstability/.../fpc/statement021014.pdf. Financial Policy Committee statement on housing market powers of Direction from its policy meeting [Accessed August 2015].

Milton Friedman. Monetary Policy: Theory and Practice. Journal of Money, Credit and Banking, 14(1):98-118, February 1982.

Milton Friedman. Money Mischief: Episodes in Monetary History. 1994.

Milton Friedman and Anna Schwartz. A Monetary History of the United States, 1867-1960. National Bureau of Economic Research, Inc, 1963. 
Douglas Gale and Martin Hellwig. Incentive-Compatible Debt Contracts: The One-Period Problem. Review of Economic Studies, 52(4):647-63, October 1985.

Simon Gilchrist and John Leahy. Monetary policy and asset prices. Journal of Monetary Economics, 49(1):75-97, 2002.

Charles Goodhart. The Evolution of Central Banks, volume 1. The MIT Press, 1 edition, 1988.

Andrew Haldane. Control rights (and wrongs), October 2011. Wincott Annual Memorial Lecture, Westminster, London.

Andrew Haldane. On being the right size, October 2012. Speech given at Institute of Economic Affairs' 22nd Annual Series, The 2012 Beesley Lectures at the Institute of Directors, Pall Mall, London.

Andrew Haldane. The age of asset management, April 2014. Speech given at London Business School, London.

Robert Hall. The long slump. American Economic Review, 101(2):431-69, 2011.

Michael Hatcher and A. Patrick Minford. Stabilisation policy, rational expectations and price-level versus inflation targeting: A survey. Journal of Economic Surveys, 30(2):327-355, 2016.

HM Treasury. Budget 2013. March 2013a. ISBN 9780102982275.

HM Treasury. Review of the Monetary Policy Framework. March 2013b. ISBN 9780101858823.

IMF. Key aspects of macroprudential policy, June 2013. URL http://www.imf .org/external/np/pp/eng/2013/061013b.pdf. Accessed August 2015. 
Olivier Jeanne and Anton Korinek. Managing Credit Booms and Busts: A Pigouvian Taxation Approach. NBER Working Papers 16377, National Bureau of Economic Research, Inc, September 2010.

Urban Jermann and Vincenzo Quadrini. Macroeconomic Effects of Financial Shocks. American Economic Review, 102(1):238-71, February 2012.

John H Kareken and Neil Wallace. Deposit insurance and bank regulation: A partial-equilibrium exposition. The Journal of Business, 51(3):413-38, 1978.

Nobuhiro Kiyotaki and John Moore. Credit Cycles. Journal of Political Economy, 105(2):211-48, April 1997.

Narayana Kocherlakota. Re-thinking leverage subsidies, 6 2011. URL https://www.minneapolisfed.org/news-and-events/presidents-speeches/rethinking-1 Remarks by Federal Reserve Bank of Minneapolis President Narayana Kocherlakota at the Tri-State Bankers Summit. Big Sky, Montana. [Accessed August 2015].

Evan F. Koenig. Monetary policy, financial stability, and the distribution of risk. Technical report, 2011.

Stefan Krasa and Anne P. Villamil. Optimal contracts when enforcement is a decision variable. Econometrica, 68(1):119-134, January 2000.

Arvind Krishnamurthy. Collateral constraints and the amplification mechanism. Journal of Economic Theory, 111(2):277-292, 2003.

Sir Andrew Large. Letter to treasury select committee, uk houses of parliament, December. 2013. 
Atif Mian and Amir Sufi. House of Debt. University of Chicago Press, 1 edition, 2015.

John Muellbauer. When is a housing market overheated enough to threaten stability? Economics Series Working Papers 623, University of Oxford, Department of Economics, September 2012.

Anton Nakov. Optimal and Simple Monetary Policy Rules with Zero Floor on the Nominal Interest Rate. International Journal of Central Banking, 4(2):73-127, June 2008.

Kalin Nikolov. Collateral amplification under complete markets. Journal of Economic Dynamics and Control, 45(C):80-93, 2014.

Charles Nolan and Christoph Thoenissen. Financial shocks and the US business cycle. Journal of Monetary Economics, 56(4):596-604, May 2009.

Charles Nolan, Plutarchos Sakellaris, and John Tsoukalas. Optimal Bank Bailouts, 2015. Mimeo.

Hugh Rockoff. Parallel journeys: Adam smith and milton friedman on the regulation of banking. Departmental working papers, Rutgers University, Department of Economics, 2010.

Kenneth Rogoff. Costs and benefits to phasing out paper currency. Scholarly articles, Harvard University Department of Economics, 2014.

Thomas Sargent. Where to draw lines: Stability versus efficiency. Economica, 78 (310):197-214, 2011.

Stephanie Schmitt-Grohe and Martin Uribe. Prudential Policy for Peggers. NBER Working Papers 18031, National Bureau of Economic Research, Inc, May 2012. 
Kevin D. Sheedy. Debt and Incomplete Financial Markets: A Case for Nominal GDP Targeting. Brookings Papers on Economic Activity, 48(1 (Spring):301$373,2014$.

Robert J. Shiller. Derivatives Markets for Home Prices. NBER Working Papers 13962, National Bureau of Economic Research, Inc, April 2008.

Robert M. Townsend. Optimal contracts and competitive markets with costly state verification. Journal of Economic Theory, 21(2):265-293, October 1979.

Paul Tucker, Simon Hall, and Aashish Pattani. Macroprudential policy at the bank of england. Bank of England Quarterly Bulletin, 53(3):192-200, 2013.

Andrew Tyrie. Letter from treasury select committee, uk houses of parliament, to bank of england governor, mark carney, November. 2013. URL https://www.parliament.uk/documents/commons-committees/treasury/131108-A.pdf.

Michael Woodford. Monetary policy in the information economy. NBER Working Papers 8674, National Bureau of Economic Research, Inc, 2001.

Michael Woodford. Inflation Targeting and Financial Stability. NBER Working Papers 17967, National Bureau of Economic Research, Inc, April 2012.

Michael Woodford. Forward Guidance by Inflation-Targeting Central Banks. CEPR Discussion Papers 9722, C.E.P.R. Discussion Papers, November 2013.

William Wright. Feeling the Squeeze: What's Happening with Pay at Investment Banks and Asset Managers? Technical report, New Financial, February 2015. 